\title{
1 Social Tourism in Greece: A Brief History of Development from the Interwar Years to the Covid-19 Era
}

\author{
Konstantinos I. Kakoudakis ${ }^{1 *}$ and Katerina Papadoulaki ${ }^{2}$ \\ ${ }^{1}$ School of Business and Management, University of Central Lancashire Pr la, \\ Larnaca, Cyprus; ' 2 Department of Mathematics and Applied Mathematics, University \\ of Crete, Heraklion, Greece
}

\subsection{Introduction}

Greece is among those European Union Member States, such as France, Belgium and Portugal, that show high levels of active state support with regard to social tourism (e.g. Walton, 2013). This is not surprising given that Greece has a long tradition in social tourism. Although it is difficult to identify the exact starting point of the development of social tourism in the country, available references show that this can be traced back to the interwar years. In the early 1930s, the newly established Greek National Tourism Organization (EOT) organized 'Sunday excursions' for the public in order to boost domestic tourism (Katsigiannis, 2017). Over time, Greece's political, social and economic environment has nurtured other motives too, such as the stimulation of national pride, the manipulation of the masses and the enhancement of all citizens' well-being and quality of life. Thus, in line with other countries, social tourism in Greece has evolved from both public and private initiatives, encompassing different motives (see La Placa and Corlyon, 2014). Its contemporary form, however, has been associated with the rise to power of the Panhellenic Socialist Movement (PASOK), which, after forming the first Greek socialist government in 1981, emphasized the provision of social welfare entitlements, especially to the lower middle class (see Pagoulatos, 2003), thus creating fruitful ground for the parallel development of social tourism in Greece.

Despite this long history though, and unlike social tourism systems in other countries, such as Belgium, France, Portugal, Spain and the UK (see Minnaert et al., 2012; Eusébio et al., 2016), very little has been written about social tourism in Greece within the international tourism literature. In fact, available information about Greek social tourism is limited to a consultancy report, 'Calypso Study on Social Tourism in Greece' (see Détente Consultants, 2010), and a recent paper by Kakoudakis and McCabe (2018). With regard to Greek bibliography, social tourism research also remains scarce, and any available studies have not intersected international literature owing to language and translation barriers, an issue that has been identified by tourism scholars in relation to non-English studies (e.g. Diekmann and McCabe, 2011). Moreover, there is a lack of available and coherent data on Greek social tourism policies and programmes. As a

*Corresponding author: kostas.i.kakoudakis@gmail.com 
result, these barriers do not facilitate a discussion on the practice of social tourism in Greece over time. As Diekmann and McCabe (2011, p. 418) point out, these limitations 'represent a gap in the transfer of knowledge between countries and between organisations and academia, which has reduced the level of overall impact of social tourism research on policy'.

While acknowledging the above limitations, the long history of social tourism practice in Greece, and its inclusion in the public policy agenda over the past several decades, makes it a particularly interesting case to study. Therefore, the present chapter attempts to bridge this gap by illustrating the process of social tourism development in Greece, from the interwar years until the present day. The chapter first sets the discussion within the context of the country's turbulent political, social and economic background, throughout most of the past century, which has exercised significant influence on the development of Greek tourism in general, and social tourism specifically. It then identifies and presents two main phases of social tourism development, highlighting important initiatives and key players that contributed to the incremental evolution of social tourism programmes in Greece, and also events that impeded their implementation and smooth running. Specific emphasis has been given to the past four decades, since this time period has largely shaped the contemporary form of Greek social tourism programmes. Therefore, the chapter explicates the close linkages between the establishment of the modern Greek welfare state in the early 1980s, and the development of social tourism as we know it today. The chapter concludes with a brief discussion on the developmental process of contemporary Greek social tourism over time, and the important socioeconomic implications of its current practice in the aftermath of the Greek financial crisis, and in the midst of the refugee crisis in Europe, and the Covid-19 pandemic.

\subsection{The Evolution of Social Tourism in Greece}

Looking at the evolution of social tourism in Greece, we can generally identify two main phases of development, according to the degree of organization, application and continuity of social tourism initiatives. The first covers the period from the interwar years until the early 1980s. It is characterized by important and, at the time, novel initiatives, which created the ground upon which contemporary social tourism was founded. Despite their significance, however, these early initiatives lacked systematic organization and continuity. The second phase began in the early 1980s and continues today. It coincides with the establishment of the modern Greek welfare state and the recognition of tourism as a social right, leading to the design of contemporary social tourism programmes, and the expansion of social tourism practice in the country. Despite their differences, however, what both phases have in common are frequent political, economic and social instabilities, which have resulted in recurrent changes in the identity and structure of tourism public administration bodies (Table 1.1), affecting the implementation of Greek tourism policy in general, and social tourism policy and practice, in particular. Arguably, the degree of significance of these changes differs greatly, resulting in respective differences in their implications for social tourism practice. What is certain, though, is that this instability has resulted in severe fluctuations in the organization and direction of Greek tourism, including social tourism, over time.

\subsubsection{Political, social and economic background}

From a chronological point of view, the first phase of social tourism development in Greece took place during particularly turbulent years, characterized by major historical events (e.g. the Asia Minor catastrophe and its socioeconomic consequences, the Greek-Italian War and the military junta in 1967-1974), and constant political change. During the interwar years, Greece suffered from many political, social and economic problems, such as unstable governance, a large volume of Asia Minor refugees and financial crises (e.g. Forster, 1958). It is because of the latter that tourism attracted government attention and was viewed as a tool for development. Eleftherios Venizelos played a significant role in 
Table 1.1. Recurrent changes in Greek tourism administration bodies (1929 - present).

\begin{tabular}{|c|c|}
\hline Date & Events \\
\hline 1929 & $\begin{array}{l}\text { Establishment of the Greek National Tourism Organization (EOT), under the } \\
\text { supervision of the Ministry of Economy }\end{array}$ \\
\hline 1935 & $\begin{array}{l}\text { Establishment of the Supreme Council of Tourism } \\
\text { Abolishment of the Supreme Council of Tourism during the same year }\end{array}$ \\
\hline 1936 & $\begin{array}{l}\text { Establishment of the Deputy Ministry of Press and Tourism, which takes over } \\
\text { the supervision of EOT } \\
\text { Abolishment of EOT and transfer of its responsibilities to the Deputy Minister of } \\
\text { Press and Tourism }\end{array}$ \\
\hline 1941 & Abolishment of the Deputy Ministry of Press and Tourism \\
\hline 1944 & Reestablishment of the Deputy Ministry of Press and Tourism \\
\hline 1945 & $\begin{array}{l}\text { Abolishment of the Deputy Ministry of Press and Tourism. Supervision of } \\
\text { tourism-related services by the president of the government } \\
\text { Establishment of the General Secretariat of Tourism }\end{array}$ \\
\hline 1946 & $\begin{array}{l}\text { Transfer of the responsibilities on tourism-related matters from the president } \\
\text { of the government to the minister of coordination. Supervision of the General } \\
\text { Secretariat of Tourism by the minister of coordination }\end{array}$ \\
\hline 1950 & $\begin{array}{l}\text { Abolishment of the General Secretariat of Tourism } \\
\text { Reestablishment of EOT, under the supervision of the minister of the } \\
\text { government's presidency }\end{array}$ \\
\hline 1951 & $\begin{array}{l}\text { Transfer of the responsibilities on tourism-related matters from the president } \\
\text { of the government to the minister of national economy. Transfer of the } \\
\text { responsibilities of the General Secretariat of Tourism to the secretary general of } \\
\text { EOT }\end{array}$ \\
\hline 1956 & $\begin{array}{l}\text { Creation of the position of a specialist tourism consultant under the supervision } \\
\text { of the president of the government }\end{array}$ \\
\hline 1965 & $\begin{array}{l}\text { Establishment of the Supreme Advisory Council of Tourism, under the } \\
\text { supervision of the minister of the government's presidency }\end{array}$ \\
\hline 1978 & Restructuring of EOT's services \\
\hline 1984 & $\begin{array}{l}\text { Transfer of the tourism-related responsibilities of the minister of the } \\
\text { government's presidency to the secretary general of EOT }\end{array}$ \\
\hline 1989 & Establishment of the Ministry of Tourism, which supervises EOT \\
\hline 1991 & $\begin{array}{l}\text { Abolishment of the Ministry of Tourism, and transfer of its responsibilities to the } \\
\text { Ministry of National Economy }\end{array}$ \\
\hline 1993 & Reestablishment of the Ministry of Tourism \\
\hline 1996 & Merger of the Ministry of Tourism with the Ministry of Development \\
\hline 1997 & Establishment of the National Council of Tourism \\
\hline 2001 & $\begin{array}{l}\text { Restructuring of EOT. Establishment of the Department of New Forms of } \\
\text { Tourism Development (including social tourism) }\end{array}$ \\
\hline 2004 & $\begin{array}{l}\text { Establishment of the Ministry of Tourism Development as an independent } \\
\text { ministry }\end{array}$ \\
\hline 2009 & $\begin{array}{l}\text { Merger of the Ministry of Tourism Development with the Ministry of Culture } \\
\text { Establishment of the new Ministry of Culture and Tourism }\end{array}$ \\
\hline 2010 & Supervision of EOT by the Ministry of Culture and Tourism \\
\hline 2012 & Reestablishment of the Ministry of Tourism as an independent ministry \\
\hline
\end{tabular}


Table 1.1. Continued

\begin{tabular}{|c|c|}
\hline Date & Events \\
\hline 2015 & $\begin{array}{l}\text { Merger of the Ministry of Tourism with the Ministries of Economy and } \\
\text { Development, respectively } \\
\text { Establishment of the new Ministry of Economy, Development and Tourism }\end{array}$ \\
\hline 2016 & Reestablishment of the Ministry of Tourism as an independent ministry \\
\hline 2018 & Main responsibility of EOT becomes the promotion of Greek tourism \\
\hline
\end{tabular}

Adapted from EOT (2012)Greek Government Gazette (1996, 2001, 2009, 2015, 2016, 2018), Raptarchis (2007).

the development of Greek tourism through several initiatives, such as the establishment of EOT (Papadoulaki, 2011). In addition, the first social tourism concepts in Greece emerged during his second administration (1928-1932), when EOT was considering ways to boost domestic tourism (Katsigiannis, 2017). The emphasis on tourism development continued during the dictatorship of Ioannis Metaxas, who took over the country's administration in 1936, as a result of national and international conjunctures. The first social tourism-related law (Law No. 2436/1940) was passed under his regime (Greek Government Gazette, 1940).

The liberation of Greece from the German occupation was followed by the civil war of 1944-1945. The next two decades after the civil war comprised a reconstruction period for the country, which was signalled by a shift from an agricultural economy to one more industrialized (see Miller, 2009). As Forster (1958, p. 229) explains, this shift resulted in "both unemployment and underemployment, contributing to the political instability of Greece... The political instability arising from these economic conditions was much increased by the Greek multi-party system which gives rise to short-lived governments.' At the time, the main objective of the Greek prime minister, Konstantinos Karamanlis, was a 'rapid expansion' of industry (e.g. steel and mining) and the tourism sector (see Miller, 2009). In the 1960s, Greece started showing some signs of economic prosperity, but new political turbulences in the mid-1960s resulted in a military coup and a 7-year dictatorship (1967-1974). After the fall of the military junta in 1974, the Greek Republic was restored and Karamanlis, leader of the liberal-conservative party Nea Democratia, took office until 1980 (Pagoulatos, 2003). One year later, the country joined the European Community.
A critical chronological point of the second phase is the early 1980s, when the modern welfare state was established in the country. The development of contemporary social tourism in Greece has evolved in parallel with the development of the Greek welfare state and has revolved around the institution of social rights. The term welfare state refers to a society that puts an emphasis on the well-being of its citizens through specific interventions, such as the provision of economic and social benefits (Goodin, 1988; Lowe, 1993). A fundamental element of the welfare state is the recognition on behalf of the state that citizens have specific social rights, the exercise of which is significant in the improvement of their quality of life (e.g. Cox, 1998). In line with this recognition, the state also recognizes its responsibility to enhance citizens' well-being and quality of life (Mishra, 1981) through various means, including the provision of social welfare. With regard to tourism, the Greek socialist government at the time recognized that the welfare state has not only the responsibility to provide less privileged citizens with the rights to education, healthcare and employment, but also with the right to holidays (Tourismos \& Economia, 1986). Hence, publicly funded holidays in Greece have been realized as a result of this recognition (see Igoumenakis et al., 1998), which is linked to the concept that going on holiday is an important indicator of social wellbeing (e.g. Haukeland, 1990; Kakoudakis et al., 2017).

Although the concept of the welfare state dates back to post-war (1945-1975) times for most Western societies, in Greece it was synthesized much later, in the early 1980s, with the first coordinated initiatives for the implementation of organized social policies (see Oikonomou, 1996, pp. 1-2). It has been argued that Greece's contemporary welfare history coincides with the rise to power of PASOK, which formed the first Greek 
socialist government in 1981 (Tsakalotos, 1998). Indeed, social tourism is inherently linked with the social democratic movements (e.g. Diekmann and McCabe, 2011), and in turn with the concepts of the welfare state and social rights (e.g. Richards, 1998). The welfare state is a major political goal of social democracy (e.g. Klitgaard, 2007) and social rights a fundamental element of the welfare state (e.g. Cox, 1998). These strong linkages largely explain why social tourism practice has a long history in regions with traditionally more social democratic ideologies (e.g. continental Europe) (Richards, 1998). Within the specific context of Greece, this also explains why social tourism became a consistent part of the country's social welfare policy during PASOK's administration.

Despite the fact that the institution of the welfare state had been questioned at an international level during this period (Oikonomou, 1996), PASOK, led by Andreas Papandreou, largely focused its political agenda on social welfare. As Pagoulatos (2003, p. 95) explains, "the rise of welfare entitlements in the first half of the 1980s served to compensate lower-middleclass strata for much of their real income losses due to the inflationary policies of the past years'. In so doing, the socialist government aimed to stabilize and strengthen its political grip by appealing to socioeconomically marginalized groups (Clogg, 1993). On the other hand, the rapid expansion of the Greek welfare state also benefited a large volume of citizens who were less in need, threatening the economic sustainability of social welfare provisions, including social tourism programmes (Igoumenakis et al., 1998). Irrespective of any bad practices and paternalist political motives, it was during this period that living standards were improved for the majority of the Greek population for the first time (Pagoulatos, 2003), resulting in the democratization of tourism. In parallel, social tourism services were properly established and incorporated into Greece's welfare policy.

\subsubsection{Phase one: From the interwar years to the early 1980 s}

In 1931, EOT's Board of Directors assessed the need to boost domestic tourism owing to the financial crisis that had hit international tourism
(Katsigiannis, 2017, p. 272). At the time, EOT had put an emphasis on the development of spa towns, and the organization of Sunday excursions for the public, with the cooperation of national railways (Katsigiannis, 2017, p. 272). During the same period, 'Emporiki' bank offered its employees special leave and subsidized visits to spa towns (Dritsas, 2008), thus acknowledging that tourism participation is linked to workers' health, well-being and productivity (e.g. Minnaert et al., 2012). Perhaps this vacation allowance for specific occupation groups was also an early recognition that those in paid employment have some sort of 'right' to a holiday (Minnaert et al., 2006, p. 8). During Metaxas' regime, the Greek state, following the trends from other, more developed, European countries (e.g. Italy and Germany), offered workers significant travel discounts on rail and boat tickets and accommodation establishments through tourism coupons. These initiatives aimed to boost domestic tourism during a period of international military crisis (see Papadoulaki, 2011, pp. 97-98). In addition, Metaxas' approach to tourism had paternalist motives that aimed to stimulate national pride and manipulate the working class through state benefits, in the form of tourism and leisure (see Vlachos, 2013). This approach resembles 'a key historical component of 'social tourism' promotion by the state, in Europe and elsewhere' (Walton, 2013, p. 57).

References about social tourism in Greece in the late 1950s and 1960s are scarce. In 1959, a pilot social tourism programme was implemented on Lesvos Island (Nikolakakis, 2013). During the 1960s, social tourism practice in Greece ranged from programmes run by the Workers' Social Benefits Organization (Ergatiki Estia) ${ }^{1}$ (a workers' fund supervised by the Ministry of Labour and Social Insurance) and campsites by the Ministry of Social Welfare and other organizations (e.g. banks, the former Social Insurance Organization [IKA] and the Hellenic Telecommunications Organization [OTE]), to initiatives organized by large enterprises (e.g. Piraiki - Patraiki and Olympic Airways) (Logothetis, 1967, p. 302). During the early years of Metapoliteusi (transition to democracy), and more specifically, in 1974, Ergatiki Estia also organized a 1-year pilot social tourism scheme with the cooperation of the Hellenic Chamber of Hotels, offering free holidays to 2000 workers 
(Tourismos \& Economia, 1974). ${ }^{2}$ This trial programme covered the full costs of hotel accommodation and food for each participant worker and at least two members of his/her family for up to 10 days. The main objectives of this initiative were to boost domestic tourism, make holidays accessible to all social classes and establish social tourism in Greece, achieving continuity in the long term.

By the late 1970s, Greek tourism stakeholders and the state had acknowledged that social tourism could be seen both as an economic development strategy and a tool to exercise social policy (Tourismos \& Economia, 1986). This renewed interest is confirmed by several significant initiatives. In 1976, for example, the Directorate H' Domestic - Social Tourism was established, under the supervision of the General Directorate of Tourism Development (Raptarchis, 2007). The Department II2 - Social Tourism of the Directorate, in cooperation with the Directorate A' Research and Development, had the responsibility of setting the necessary requirements for the development of social tourism. The Greek government at the time also considered it advisable to establish knowledge transfer partnerships with countries that had well-developed social tourism systems, such as France, in order to develop Greek social tourism upon solid foundations (Centre of Planning and Economic Research [KEPE], 1987). Indeed, in 1981, EOT signed a cooperation protocol with a French social tourism association; however, this ended soon after (KEPE, 1987).

\subsubsection{Phase two: From the early 1980s to the present}

The previous section shows that until 1980, the initiatives regarding social tourism appear to reflect single cases that lacked coherence and continuity, both with regard to their organization and implementation. Social tourism programmes in Greece started taking their current form in 1982, when EOT, Ergatiki Estia and the General Secretariat for Youth first launched social tourism programmes as we know them today (e.g. Igoumenakis et al., 1998). EOT's first social tourism programme was also a pilot programme, which ran from 1982 until 1983 in cooperation with Ergatiki Estia and with the participation of EOT-owned hotels ('Xenia' Hotels) (Katsigiannis, 2017). The programme offered some valuable conclusions in relation to beneficiaries and providers. With regard to the former, it identified the specific social groups that should participate in the first social tourism programmes; with regard to the latter, it demonstrated the necessity of cooperation with other public and private organizations and trade unions (Tourism Issues, 1983). Since then, social tourism programmes in Greece have been largely organized and run by public authorities with the close cooperation of other public (e.g. Greek National Railways [OSE], the Common Collection Funds of Coaches [KTEL]) and private (hotels, campsites, and cruise lines) organizations, forming part of social policy (Igoumenakis et al., 1998).

These partnerships have significantly contributed to the establishment of social tourism in Greece as a successful institution (Katsigiannis, 2017). This is confirmed by the available budget and large volume of beneficiaries. For example, during the first implementation period, until the mid-1980s, it is estimated that social tourism received 1.5 billion drachmas (about $€ 4.4$ million) of public funding, and benefited approximately 700,000 individuals and numerous businesses across the country (Tourismos \& Economia, 1986). In addition to the main publicly funded social tourism programmes, some other important initiatives can be identified within the framework of wider social policy and trade union activities, such as vacation settlements for specific occupation groups (e.g. bank clerks, teachers and Greek army officers) and campsites for specific sociodemographic groups (e.g. the elderly, through the Open Care Centres for the Elderly [KAPI], and children with physical and mental disabilities, through the Patriotic Institution of Social Welfare and Awareness [PIKPA]) (see Sotiriadis, 1994).

From the early 1980s until the mid-2010s, EOT and Ergatiki Estia had been the main social tourism providers in Greece. ${ }^{3}$ EOT also played a significant role in raising public awareness of social tourism and its socioeconomic benefits, and in developing more varied social tourism programmes, which aimed to expand the provision of tourism services to different sociodemographic groups. For example, in 1986, EOT's president 
chaired the International Bureau of Social Tourism Conference, held in Athens, which revolved around the economic and social implications of social tourism (Tourismos \& Economia, 1986). Moreover, from the mid-1980s until the early 1990s, EOT launched social tourism subprogrammes, such as a winter youth tourism programme in popular ski centres; a therapeutic tourism programme in spa towns around Greece; and a 7-day holiday in Cyprus ${ }^{4}$ (see Katsigiannis, 2017). Ergatiki Estia had a fundamental role, offering several social tourism programmes for almost three decades - from 1983 until 2012 (OEE, n.d).

On the other hand, and in spite of this significant progress during the 1980s, the practice of social tourism in Greece has not been smooth. During most of the 1990s, the country's economy was stagnant (for several reasons, e.g. budget deficit, low investment and high inflation), and under the supervision of the European Commission and the International Monetary Fund (IMF), which aimed to ensure reduction of the budget deficit (Close, 2002). These circumstances had significant negative effects on the Greek welfare state, and on the living standards of much of the population (e.g. restrained wages and social benefits, and increased taxation for prolonged periods) (Pagoulatos, 2003). Consequently, this climate of economic austerity had major implications for social tourism programmes. By the late 1980s, public funding was reduced, resulting in the shrinkage of EOT's programmes and, in turn, in significant reductions in the number of beneficiaries (Sotiriadis, 1994). Despite these adverse conditions, some important public initiatives can be still identified. In 1990, for example, EOT established the third General Directorate of Administration and Capitalization, and its Sub-Directorate of Domestic and Social Tourism ('Directorate H'), which supervised the implementation of social tourism programmes (Raptarchis, 2007).

The Greek economy began to recover in the mid-1990s. Indicative of this is that in 1995-2000, Greece became one of the best performers in the EU, reaching an annual average of $3.1 \%$ growth rate in GDP (Pagoulatos, 2003). In turn, this economic climate appeared to have positive implications for the practice of social tourism programmes in Greece. For example, in 1995, the provision of subsidized holidays for pensioners of the Greek Bar Fund (who did not receive pension from any other social fund) was initiated (Presidential Decree No. 225/1995) (Greek Government Gazette, 1995). The period of fast economic growth continued after Greece joined the euro zone in 2000-2008 (Matsaganis, 2011), and brought about positive changes in various sectors of the national economy, including tourism. Within this positive economic climate, the practice of social tourism thrived. In 2002, the Farmers' Welfare Account (Agrotiki Estia) was established within the Agricultural Insurance Organization (OGA) with the aim of organizing and implementing social tourism programmes for farmers, retired farmers and pensioners of the Non-Insured Elderly Account (Law No. 3050/2002) (Greek Government Gazette, 2002). In 2007-2008, EOT implemented its newly named 'Tourism for All' programme, including a specific subprogramme for seniors. During the first years of its implementation, the programme had a $€ 15$ million annual budget (Détente Consultants, 2010). Other important social tourism players during this period were the General Secretariat for Youth, unions and other insurance organizations (e.g. IKA, and the Mutual Health Fund of National Bank of Greece Personnel [TYPET]) (Détente Consultants, 2010).

The 2010s have been a period of deep economic recession for Greece, with significant consequences for society in general, and the Greek welfare state specifically (e.g. Matsaganis, 2011). As a result, social tourism practice has not remained unaffected. In 2012, one of the main and most successful providers of social tourism programmes in Greece, Ergatiki Estia, was shut down, affecting numerous of citizens and hospitality SMEs (Kathimerini, 2012). In 2013, all the rights and responsibilities of Ergatiki Estia, including the provision of social tourism programmes, were transferred to the Manpower Employment Organization (OAED) (Law No. 4144/2013) (OAED, n.d). In 2014, EOT's "Tourism for All” programme (including its sub-programme for seniors), the flagship social tourism programme in Greece, stopped running, and since then, to the best of our knowledge, it has been inoperative. ${ }^{5}$ During the last period of its implementation in 2013-2014, the programme's budget had dropped to $€ 5$ million (EOT, 2013). It can be argued that these 
two events marked the end of an era for the two major providers of Greek social tourism for more than three decades. During the same year, the main responsibility for the design and implementation of social tourism programmes was transferred to the Department of New Forms of Tourism within the Ministry of Tourism (Greek Government Gazette, 2014).

\section{Current programmes}

Today, social tourism in Greece is largely organized and run by OAED and the Organization of Welfare Benefits and Social Solidarity (OPEKA, formerly OGA), while also encompassing smaller players, including unions, as well as other public and private organizations. Bank employees' associations, for instance, organize summer camps for their members' children (e.g. TYPET, 2018). With regard to the two major social tourism programmes run by OAED and OPEKA, these operate all year round, and mainly offer partially funded holidays, through coupons (subsidies), to different sociodemographic groups, such as employed and unemployed individuals, pensioners, people with disabilities (the carers of people with $67 \%$ disability or more are also eligible to participate) and their protected family members (OAED, 2018a; OPEKA, 2018). The eligibility criteria vary to some extent, depending on the provider; however, what all public programmes have in common is that their beneficiaries live on low incomes and have not participated in any other social tourism programme over the past year. With regard to accommodation suppliers, all types of hotels, rental rooms and campsites around Greece with a valid 'Special Operation Logo' are eligible to participate. Moreover, special emphasis has been given to the equal treatment of social tourists, through explicitly set responsibilities for hotel managers, in relation to the provision of good quality services and facilities (see OPEKA, 2018).

To a larger or lesser extent, the duration of holidays, the number of beneficiaries and the amount of subsidies differ among providers and programmes. For example, OAED's 2018-2019 programme had a $€ 10$ million budget, and offered up to five overnight stays to 140,000 beneficiaries, and up to ten overnight stays to those who choose to spend their holidays on the islands of Lesvos, Chios, Samos, Leros and Kos (OAED, 2018a). The aim of the latter initiative was to boost tourism activity in the North Aegean Islands, which have experienced a reduction in tourist demand owing to the refugee crisis in the region. This action resembles the practice of successive French governments, who have used the 'Chèque-Vacances' system to stimulate tourism activity in specific areas (see Davidson and Maitland, 1997). In addition, OAED runs a 'Camp for Kids' programme, with a €35 million budget, aiming to benefit 70,000 children (OAED, 2018b). The other major provider, OPEKA, offers social tourism holidays, through the Farmers' Welfare Account (Agrotiki Estia). Its 2018-2019 programmes included: 'Social Tourism' - up to 6 days for 55,000 beneficiaries, 'Therapeutic Tourism' - up to 6 days for 4000 pensioners, 'Camping Programme for Kids' - up to 16 days for 1000 children of beneficiaries and 'Four-Day Trips' for 12,500 beneficiaries (OPEKA, 2018). OPEKA also has a special offer (full accommodation subsidy, excluding breakfast) for those beneficiaries who choose to visit the North Aegean Islands and the Dodecanese. During the Covid-19 pandemic, and owing to its massive impact on international arrivals, the Greek Government has put a special emphasis on social tourism, as a means to boost domestic tourism (Greek Government, 2020). Right after the end of lockdown in the country, the government announced the implementation of a strengthened 'Tourism for All' programme for 2020-2021, through OAED. The budget of the programme has been significantly increased, reaching $€ 37$ million, and offering 370,000 vouchers $(164 \%$ more compared with the previous year) (ETHNOS, 2020). In so doing, the Greek state has increased the amount of subsidy (while decreasing the amount of individual contribution), and the number of overnight stays from 5 to 6 , has offered up to 10 overnight stays in Lesvos, Chios, Samos, Leros, Kos and Evros Regional Unit (with zero individual contribution), and has subsidized ferry tickets for the first time (OAED, 2020).

\subsection{Conclusion}

Social tourism is not a new concept in Greece. On the contrary, it has a long tradition, which 
can be traced back to the interwar years, when EOT was considering ways to boost domestic tourism during a period of international crisis. It has been mainly supported by the public sector, with the significant contribution of private organizations and labour unions, and it has seen growing interest, especially since the early 1980 s when it was incorporated into the country's social welfare policy (Katsigiannis, 2017). However, this long history is rather unknown at an international level, as the case of Greek social tourism has not intersected tourism literature, mainly owing to the scarcity of relevant research and language barriers alike. This chapter has aimed to bridge this gap by presenting and discussing the development of social tourism in Greece over time, from its emergence during the interwar years until today. In so doing, it has become evident that Greek social tourism has been developed within a turbulent political, economic and social environment, largely characterized by instabilities and recurrent political changes. This environment has shaped the underlying motives for its development, and has exercised significant effects on its organization and practice (e.g. fluctuations in public funds, different priorities of successive governments in relation to public expenditure and, consequently, changes in the number of providers, programmes and beneficiaries, and the length of subsidized holidays). This confirms that social tourism is not a static but a dynamic concept (Minnaert et al., 2012), and, therefore, any investment in social tourism is analogous to the political, economic and social circumstances of different regions at different periods of time.

It was identified that a plethora of initiatives, from the interwar period until the early years of Metapoliteusi, created the ground upon which contemporary social tourism is founded in Greece. However, it was in the early 1980s that Greek social tourism took its current form, becoming part of social welfare policy and consequently becoming more widely practised. This occurred in parallel with the rise to power of the first Greek socialist government, in 1981, and the establishment of the modern Greek welfare state. Indeed, it was during this period, when the connection between social tourism, social welfare and social rights became stronger in Greece, that a more systematic approach to social tourism development emerged. Although PASOK's administration had paternalist motives in relation to the implementation of social welfare policies, the wide practice of contemporary social tourism in Greece has evolved around the institution of social rights, and state recognition that less privileged citizens also have the right to holidays, among other important rights (Tourismos \& Economia, 1986). In addition, the aim to boost domestic tourism has remained another major motive that still mobilizes the organization and application of social tourism programmes, emphasizing a more equal distribution of tourist flows throughout the year, and across regions. This has been especially pertinent in the aftermath of the Greek financial crisis, as well as in the midst of the current refugee crisis in Europe, and the Covid-19 pandemic.

Undoubtedly, Greek social tourism has been largely affected by these major phenomena, but, in parallel, it has also been addressing them through new initiatives. For example, the climate of economic austerity in Greece over the past fewyears has had significant implications for social tourism practice (e.g. abolishment of key providers and major programmes, such as Ergatiki Estia and EOT's 'Tourism for All' programme). In spite of these challenges, however, Greek social tourism has proved resilient, and continues to directly benefit thousands of disadvantaged individuals and accommodation businesses every year (e.g. OGA, 2017; OAED, 2018a). Today, it is mainly provided by two public organizations, OAED and OPEKA, while also encompassing smaller-scale initiatives, including programmes run by private organizations (e.g. banks). Specific emphasis has been placed on social tourism programmes for children due to the severe consequences of the financial crisis (e.g. high unemployment, acute poverty, risk of poverty and social exclusion) for a large proportion of Greek households (Hellenic Statistical Authority [ELSTAT, 2016). In the same manner, an emphasis has been recently put on the promotion of host communities that suffer from low tourism demand due to the refugee crisis in the region (e.g. the North Aegean Islands) as destinations for social tourists (OAED, 2018a). Most importantly, social tourism has been playing a major role during the Covid-19 pandemic. In this unprecedented global crisis that has paralysed international tourism, social tourism has been placed at the centre of Greece's 
tourism strategy, as one of the few remaining developmental tools with sustainable characteristics that have the potential to support domestic tourism. Arguably, these initiatives are of the utmost importance, as they address (at least partly) some of the major current socioeconomic problems of Greece, including those related to the Covid-19 pandemic. Considering the complex and multidimensional economic, social and public health impacts of major crises (e.g. decline in tourism demand, increase of unemployment rates and increased risk of mental ill-health), forms of social welfare such as social tourism can offer some relief to vulnerable social groups and businesses, alike (Kakoudakis, 2020). Therefore, in this new and particularly turbulent environment that has been shaping over the past decade, and especially since the Covid-19 outbreak, the state has the responsibility to safeguard social tourism, and to take advantage of its full potential. For example, initiatives that will increase public awareness of the multiple benefits of social tourism, public-private partnerships and the inclusion of more providers (e.g. tourist and travel agencies) in future programmes, are deemed necessary towards this direction, and for the long-term sustainability of social tourism in Greece.

\section{Notes}

${ }^{1}$ Ergatiki Estia did not receive funding from the state budget, but its resources came exclusively from workers' and employers' contributions (OEE, 2012).

2 The programme was organized during the Greek military junta, and it was probably launched sometime just before its fall, in July 1974. The article referred to was issued in July-August, 1974, and it includes an interview with Mr Paparrodopoulos, Minister of Labour during the first half of 1974.

${ }^{3}$ EOT had the responsibility for the beneficiaries working in the public sector, and Ergatiki Estia for those working in the private sector (see Sotiriadis, 1994).

${ }^{4}$ The programme had a budget of 55 million drachmas, and benefited thousands of Greeks (see Katsigiannis, 2017).

${ }^{5}$ To confirm this, we contacted the headquarters of EOT by phone.

\section{Acknowledgements}

We would like to thank Dr Vicky Story, professor of marketing and director of MBA programmes at Loughborough University, for taking the time to read our manuscript and give us her valuable feedback.

\section{References}

Clogg, R. (1993) Greece 1981-1989: the Populist Decade. Macmillan, London.

Close, D.H. (2002) Greece Since 1945: Politics, Economy and Society. Pearson Education, London.

Cox, R.H. (1998) The consequences of welfare reform: how conceptions of social rights are changing. Journal of Social Policy 27(1), 1-16. DOI: 10.1017/S0047279497005163.

Davidson, R. and Maitland, R. (1997) Tourism Destinations. Hodder and Stoughton, London.

Détente Consultants (2010) Calypso study on social tourism: Greece. European Commission. Available at: http://ec.europa.eu/DocsRoom/documents/6936?locale=en (accessed 23 November 2018).

Diekmann, A. and McCabe, S. (2011) Systems of social tourism in the European Union: a critical review. Current Issues in Tourism 14(5), 417-430. DOI: 10.1080/13683500.2011.568052.

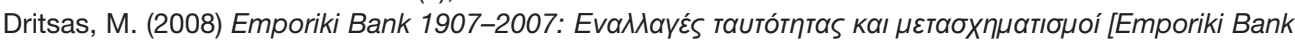
1907-2007: Identity changes and transformations]. Emporiki Bank of Greece, Athens.

ELSTAT (2016) Greece in figures: October-December 2016. Available at: www.statistics.gr/en/greece-infigures (accessed 21 November 2018). 


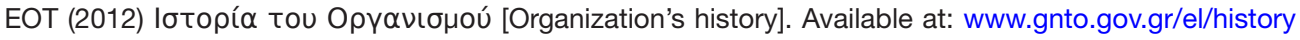
(accessed 1 December 2018).

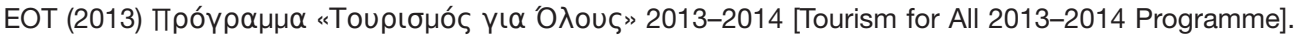
Available at: www.koinonikostourismos.gr/pdfs/tourgiaolous2013_2014.pdf (accessed 21 November 2018).

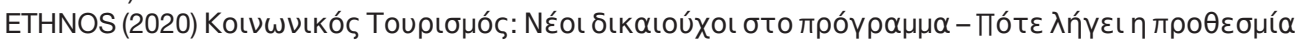
[Social Tourism: New beneficiaries - Programme's deadline]. Available at: https://www.ethnos.gr/ oikonomia/114167_koinonikos-toyrismos-neoi-dikaioyhoi-sto-programma-pote-ligei-i-prothesmia (accessed 21 October 2020).

Eusébio, C., Carneiro, M.J., Kastenholz, E. and Alvelos, H. (2016) The impact of social tourism for seniors on the economic development of tourism destinations. European Journal of Tourism Research 12, $5-24$.

Forster, E.S. (1958) A Short History of Modern Greece, 1821-1956, 3rd rev. edn. Methuen \& Co. Ltd, London.

Goodin, E. (1988) Reasons for Welfare: The Political Theory of the Welfare State. Princeton University Press, Princeton, New Jersey.

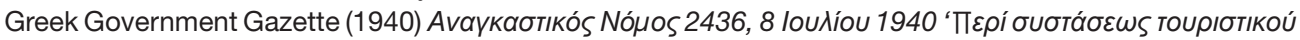

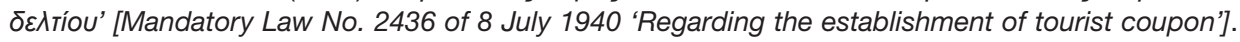
National Printing Office, Athens.

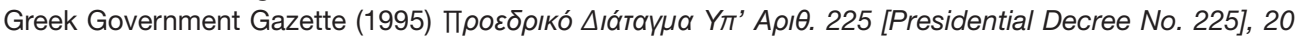
June. National Printing Office, Athens.

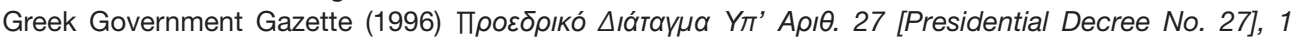
February. National Printing Office, Athens.

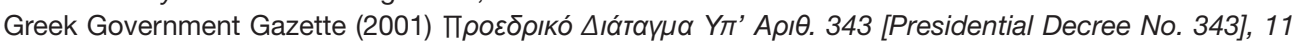
October. National Printing Office, Athens.

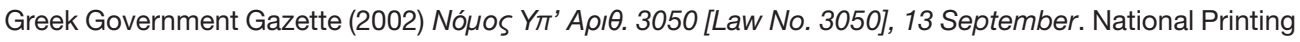
Office, Athens.

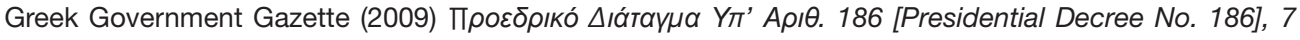
October. National Printing Office, Athens.

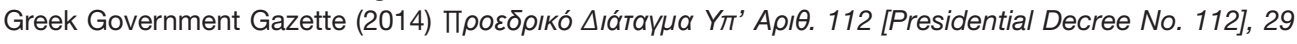
August. National Printing Office, Athens.

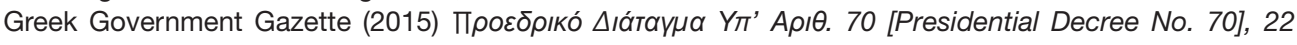
September. National Printing Office, Athens.

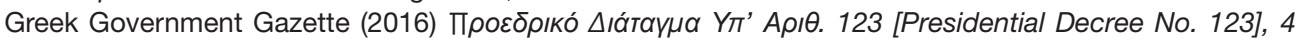
November. National Printing Office, Athens.

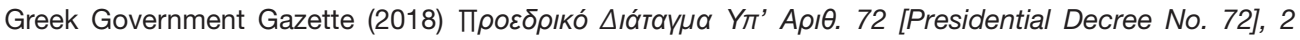
August. National Printing Office, Athens.

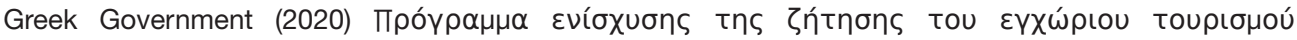

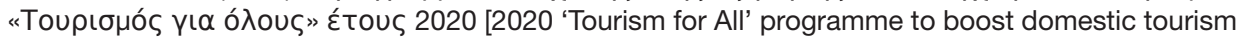
demand]. Available at: https://covid19.gov.gr/programma-enischysis-tis-zitisis-tou-egchoriou-tourismou-tourismos-gia-olous-etous-2020/ (accessed 21 October 2020).

Haukeland, J.V. (1990) Non-travellers: The flip side of motivation. Annals of Tourism Research 17(2), 172-184.

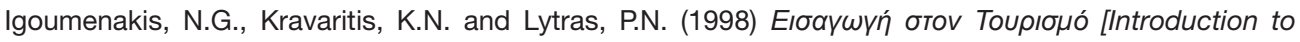
Tourism]. Interbooks, Athens.

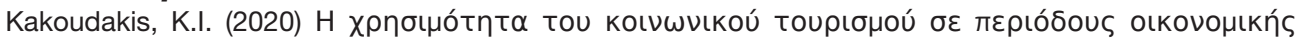

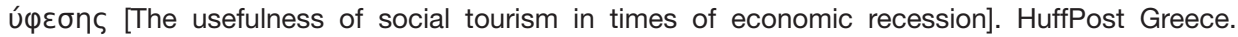
Available at: https://www.huffingtonpost.gr/entry/e-chresimoteta-toe-koinonikoe-toerismoe-se-periodoes-oikonomikes-efeses_gr_5eb265cbc5b6f8deb4e97b0d (accessed 22 October 2020).

Kakoudakis, K.I. and McCabe, S. (2018) Social tourism as a modest, yet sustainable, development strategy: policy recommendations for Greece. Journal of Policy Research in Tourism, Leisure and Events 10(3), 189-203. Available at: https://doi.org/10.1080/19407963.2018.1443938 DOI: 10.1080/19407963.2018.1443938.

Kakoudakis, K.I., McCabe, S. and Story, V. (2017) Social tourism and self-efficacy: exploring links between tourism participation, job-seeking and unemployment. Annals of Tourism Research 65, 108121. Available at: https://doi.org/10.1016/j.annals.2017.05.005 


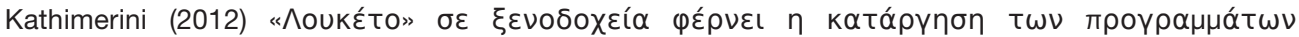

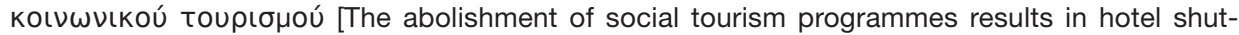
downs]. Available at: www.kathimerini.gr/451515/article/oikonomia/epixeirhseis/loyketo-se-3enodoxeia-fernei-h-katarghsh-twn-programmatwn-koinwnikoy-toyrismoy (accessed 7 December 2018).

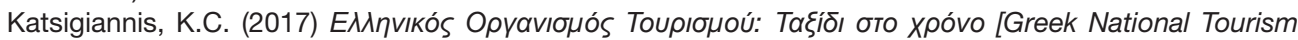
Organization: Journey in Time]. Mitropolis, Athens.

KEPE (1987) Programming Issues E9. Reports for the 1983-1987 Programme: Tourism. KEPE, Athens.

Klitgaard, M.B. (2007) Why are they doing it? Social democracy and market-oriented welfare state reforms. West European Politics 30(1), 172-194. DOI: 10.1080/01402380601019753.

La Placa, V. and Corlyon, J. (2014) Social tourism and organised capitalism: research, policy and practice. Journal of Policy Research in Tourism, Leisure and Events 6(1), 66-79. DOI: 10.1080/19407963.2013.833934.

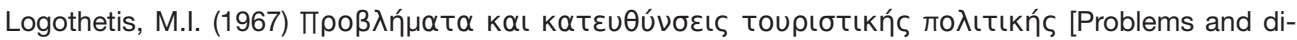
rections of tourism policy]. Unpublished PhD thesis. Panteion University of Social and Political Sciences, Athens, Greece.

Lowe, R. (1993) The Welfare State in Britain Since 1945. Macmillan, Houndmills and London.

Matsaganis, M. (2011) The welfare state and the crisis: the case of Greece. Journal of European Social Policy 21(5), 501-512. DOI: 10.1177/0958928711418858.

Miller, J.E. (2009) The United States and the Making of Modern Greece: History and Power, 1950-1974. University of North Carolina Press, Chapel Hill, North Carolina.

Minnaert, L., Maitland, R. and Miller, G. (2006) Social tourism and its ethical foundations. Tourism Culture \& Communication 7(1), 7-17. DOI: 10.3727/109830406778493533.

Minnaert, L., Diekmann, A. and McCabe, S. (2012) Defining social tourism and its historical context. In: McCabe, S., Minnaert, L. and Diekmann, A. (eds) Social Tourism in Europe: Theory and Practice. Channel View Publications, Bristol, UK, pp. 18-30.

Mishra, R. (1981) Society and Social Policy, Theories and Practice of Welfare, 2nd edn. Macmillan, London.

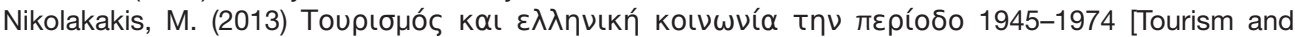
Greek society during the period 1945-1974]. Unpublished PhD thesis. University of Crete, Heraklion, Greece.

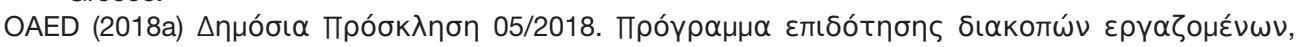

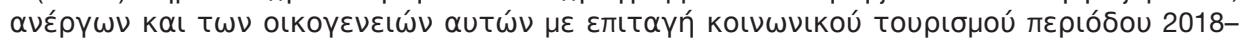
2019 [Public call 05/2018. 2018-2019 programme of subsidised holidays for employed and unemployed individuals, and their families, through social tourism coupons]. Available at: www.oaed.gr/ koinonikos-tourismos-2018-2019 (accessed 9 September 2019).

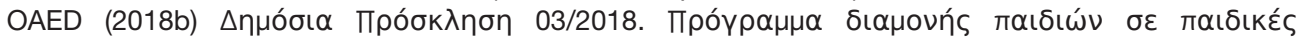

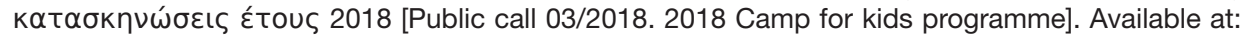
www.oaed.gr/kataskenotiko-programma (accessed 9 September 2019).

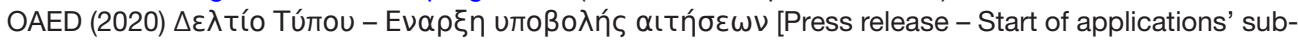
mission]. Available at: www.oaed.gr/koinonikos-tourismos-2020-2021 (accessed 21 October 2020).

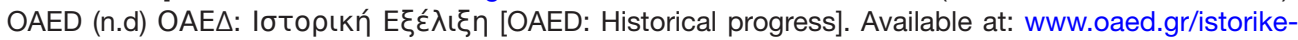
exelixe (accessed 23 June 2019).

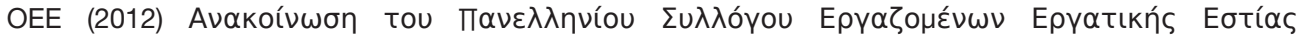
[Announcement of the Panhellenic Association of Ergatiki Estia's employees]. Available at: www.oee. $\mathrm{gr} /$ (accessed 10 November 2019).

OEE (n.d) Koıvwvikóৎ Toupı бuóৎ [Social tourism]. Available at: www.oee.gr/koinonikos_tourismos.html (accessed 7 December 2018).

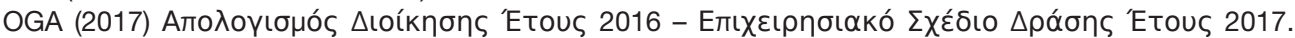
[2016 Administration Review - 2017 Operational Action Plan]. Available at: www.oga.gr/\# (accessed 23 November 2018).

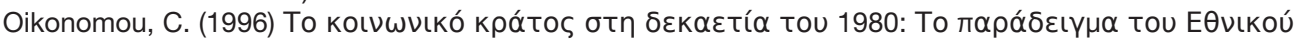

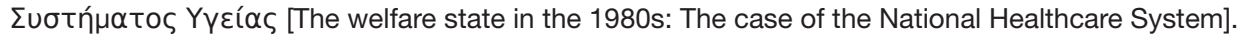
Unpublished PhD thesis. Panteion University of Social and Political Sciences, Athens, Greece.

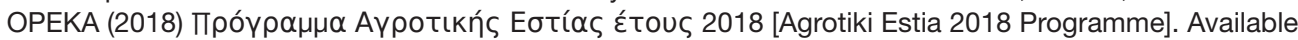
at: www.koinonikostourismos.gr/pdfs/pliroforiesAgr_Estia_2018.pdf (accessed 17 September 2019).

Pagoulatos, G. (2003) Greece's New Political Economy: State, Finance, and Growth from Postwar to EMU. Palgrave Macmillan, London/New York. 


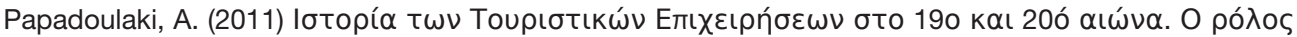

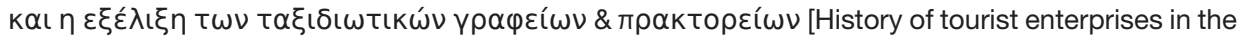
19th and 20th century. The role and development of tourist bureaus and agencies]. Unpublished PhD thesis. Hellenic Open University, Patras, Greece.

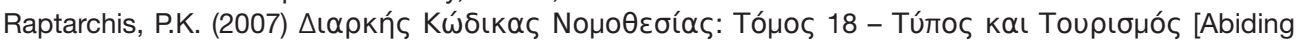
Law Code: Vol. 18 - Press and Tourism]. Hellenic Republic, Ministry of Interior. Available at: www. e-themis.gov.gr/Portal/Default.aspx?Page=downloads (accessed 23 June 2019).

Richards, G. (1998) Time for a holiday? Social rights and international tourism consumption. Time and Society $7,145-160$.

Sotiriadis, M. (1994) Toupıбтıкń Поגıтıкń [Tourist Policy]. Technological Educational Institute of Crete, Heraklion, Crete.

Tourism Issues (1983) KoIvwvikós Toupıбuós [Social Tourism], pp. 46-.47.

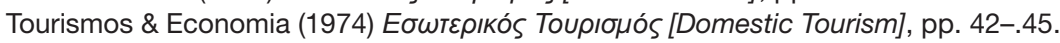

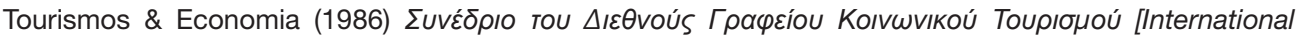
Bureau of Social Tourism Conference], p. 40.

Tsakalotos, E. (1998) The political economy of social democratic economic policies: The Pasok experiment in Greece. Oxford Review of Economic Policy 14(1), 114-138. DOI: 10.1093/oxrep/14.1.114.

TYPET (2018) Camps. Available at: http://typet.gr/index.php/en/camp (accessed 9 September 2019).

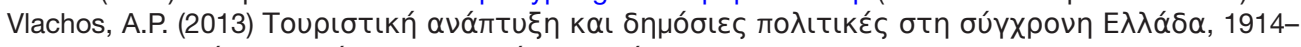

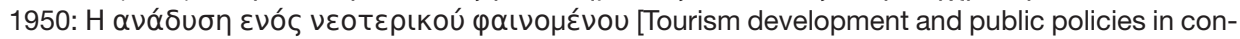
temporary Greece, 1914-1950: The emergence of a modernist phenomenon]. PhD thesis. National and Kapodistrian University of Athens, Athens, Greece.

Walton, J.K. (2013) 'Social tourism' in Britain: history and prospects. Journal of Policy Research in Tourism, Leisure and Events 5(1), 46-61. DOI: 10.1080/19407963.2012.703377. 